\title{
Analisis Pendapatan Usahatani Kacang Hijau di Kecamatan Wewiku Kabupaten Malaka
}

\author{
Adiyanti Hoar Tetik ${ }^{\mathrm{a}}$, dan Yosefina Marice Fallo ${ }^{\mathrm{b}}$ \\ ${ }^{a}$ Fakultas Pertanian, Universitas Timor, Kefamenanu, TTU - NTT, Indonesia. \\ ${ }^{b}$ Fakultas Pertanian, Universitas Timor, Kefamenanu, TTU - NTT, Indonesia.
}

\section{Article Info}

Article history:

Received 23 Juni 2016

Received in revised form 8 Juli 2016

Accepted 15 Juli 2016

\section{Keywords:}

Analisis Pendapatan

Usahatani Kacang Hijau

Wewiku

\section{Abstrak}

Penelitian ini bertujuan untuk mengetahui gambaran usahatani kacang hijau di Kecamatan Wewiku Kabupaten Malaka, mengetahu besarnya pendapatan yang diperoleh petani dari usahatani kacang hijau di Kecamatan Wewiku Kabupaten Malaka, dan mengetahui besarnya keuntungan relatif dari usahatani kacang hijau di Kecamatan Wewiku Kabupaten Malaka. Dilaksanakan di Kecamatan Wewiku Kabupaten Malaka mulai dari bulan Mei sampai dengan bulan Juni 2016. Teknik pengambilan sampel dilakukan secara random sampling dari populasi yang berjumlah $525 \mathrm{kk}$ sehingga total responden 52 orang. Metode analisis data yang digunakan adalah analisis deskripti kuantitatif untuk menegetahui tujuan pertama, analisis pendapatan untuk mengetahui tujuan kedua, dan analisis keuntungan rela tive untuk mengetahui tujuan ketiga. Berdasarkan hasil penelitian dapat digambarkan bahwa tahapan usahatani kacang hijau terdiri dari persiapan lahan, persiapan benih, penanaman, penyiangan, panen dan pasca panen. Besarnya pendapatan usahatani kacang hijau tertinggi sebesar Rp. 2.225.125 dan terendah Rp. (2.482) dengan rata-rata Rp. 1.493.494. Tinggi rendahnya pendapatan tergantung dari biaya yang dikeluarkan, harga jual dan produksi kacang hijau pada musim tanam 2015/2016. Nilai rata-rata R/C ratio dari usahatani kacang hijau sebesar 2,2 maka dapat disimpulkan bahwa usahatani kacang hijau secara ekonomis menguntungkan sehingga usahatani tersebut mempunyai prospek yang lebih baik untuk terus dikembangakan. (2016 dipublikasikan oleh Agrimor.

\section{Pendahuluan}

Ketahanan pangan adalah salah satu kebijakan yang bersifat menyelaraskan kegiatan-kegiatan yang menunjang ketersediaan distribusi dan konsumsi pangan agar setiap individu dapat mengakses pangan dan mengelola konsumsinya untuk meningkatkan nilai gizi masyarakat melalui penyediaan protein, meningkatkan ekspor hasil pertanian, memperluas lapangan kerja pertanian, juga mendorong untuk meningkatkan pendapatan petani.

Menurut Rukmana, (1997) manfaat kacang hijau sangat besar bagi kelangsungan hidup manusia yaitu Bahan pangan (bubur, sayur dan kue-kue), penunjang gizi dalam $100 \mathrm{~g}$ biji kering, kacang hijau terkandung 10,7 \% air, karbohidrat $1,19 \mathrm{~g}$, serat kasar $118 \mathrm{mg}$, kalsium $340 \mathrm{mg}$, pospor $7,7 \mathrm{mg}$, besi 6 $\mathrm{mg}$, sodium $1,027 \mathrm{mg}$, kalium $77,3 \mathrm{mg}$, vitamin A $0,38 \mathrm{mg}$, Thiamine $0,21 \mathrm{mg}$ dan riboflavin 2,6 mg, peningkatan pendapatan petani (nilai ekonomi tinggi), penunjang kesehatan (baik penderita penyakit beri-beri berkhasiat sebagai anti sterilitas), dan menunjang kesuburan tanah.

Begitu besar manfaatnya, maka permintaan terhadap hasil kacang hijau cukup tinggi dan cenderung meningkat dari tahun ke tahun. Rukmana (1997) menyatakan bahwa permintaan produksi kacang-kacangan termasuk kacang hijau pada masa mendatang diperkirakan meningkat terus sejalan dengan pertambahan jumlah penduduk dan perbaikan gizi masyarakat, dan mengacu kepada pola pangan harapan (PPH) tahun 2000, bahwa konsumsi kacangkacangan untuk penduduk Indonesia rata-rata 35,88 gram kapital/hari.

Program ketahanan pangan yang dilakukan melalui peningkatan produksi pangan di Kecamatan Wewiku salah satu komoditinya adalah tanaman kacang hijau. Jenis varietas yang digunakan di Kecamatan Wewiku adalah Vima 1 dan Lokal. Sedangkan komoditi lain yang diusahakannya yaitu jagung, padi, dan ubi kayu.

Kacang hijau merupakan salah satu komoditi kacang-kacangan yang mempunyai arti penting bagi masyarakat, baik dilihat dari nilai ekonominya yang tinggi maupun dari kandungan gizinya.

Menurut data BPS Kabupaten Malaka (2015), pada tahun 2014 tanaman kacang hijau di Kecamatan Wewiku sebesar 721 ton dengan luas panen sebesar 800 ha dan produktivitasnya $9,01 \mathrm{kw} / \mathrm{ha}$

Tujuan dari usahatani kacang hijau sebagai penggunaan hasil produksi, selain untuk dikonsumsi, sumbang, bibit dan juga untuk dijual guna memperoleh pendapatan dan keuntungan. Besar atau kecilnya keuntungan usahatani sangat tergantung pada efisiensi sumber daya yang digunakan petani dalam usahatani maka petani dapat melakukan penekanan biaya produksi sehingga memperoleh keuntungan yang sebesar-besarnya .

Berdasarkan uraian di atas maka penulis ingin meneliti tentang pendapatan usahatani kacang hijau. Usahatani kacang hijau menjadi salah satu usahatani yang sangat penting bagi masyarakat setempat karena hasil yang didapatkan sangat menonjol, sehingga ada beberapa kendala yang dihadapi oleh petani di Kecamatan Wewiku yakni besarnya pendapatan dan kurangnya perhitungan terhadap perkembangan yang diperoleh dari usahatani sehingga dapa menguntungkan atau merugikan, untuk itu perlu dilakukan penelitian tentang analisis pendapatan usahatani kacang hijau di kecamatan Wewiku kabupaten Malaka.

Tujuan penelitian ini adalah 1) Untuk mengetahui gambaran usahatani kacang hijau di Kecamatan Wewiku Kabupaten Malaka; 2) Untuk mengetahui besar pendapatan yang diperoleh petani dari usahatani kacang hijau di Kecamatan Wewiku Kabupaten Malaka; dan 3) Untuk mengetahui keuntungan relatif dari usahatani kacang hijau di Kecamatan Wewiku Kabupaten Malaka.

\section{Metode}

Penelitian dilaksanakan di Kecamatan Wewiku Kabupaten Malaka mulai dari bulan Mei sampai dengan bulan Juni 2016. Teknik pengambilan sampel dilakukan secara random sampling dari populasi yang berjumlah $525 \mathrm{kk}$ sehingga total responden 52 orang. Metode analisis data yang digunakan adalah analisis deskriptif kuantitatif untuk mengetahui tujuan pertama, analisis pendapatan untuk mengetahui tujuan kedua, dan analisis keuntungan relatif untuk mengetahui tujuan ketiga.

Analisis deskriptif kualitatif merupakan analisis yang berguna untuk menggambarkan variabel yang diteliti (Ratna, 2009). Analisis ini digunakan untuk mengetahui gambaran usahatani kacang hijau yang dilakukan $d$ Kecamatan Wewiku. Untuk mengidentifikasi masalah besarnya pendapatan usaha maka dilakukan analis pendapatan sesuai petunjuk (Soekartawi, 1995). Untuk mengetahui keuntungan relatif dari usahatani kacang hijau digunakan analisis R/C Ratio sesuai petunjuk Soekartawi (2006).

\section{Hasil dan Pembahasan}

\subsection{Deskripsi Usahatani Kacang Hijau}

Gambaran kegiatan usahatani kacang hijau di Kecamatan Wewiku dapat di jelaskan sebagai berikut :

a. Persiapan dan pengolahan lahan

Persiapan lahan berupa pembersihan lahan yang dilakukan setelah pemanenan jagung. Pembersihan lahan dilakukan dengan cara mengumpulkan sisa-sisa batang jagung dan rerumputan kemudian dibakar. Sedangkan sebagian besar petani menggunakan sistem pengolahan lahan ( balik tanah ) dengan menggunakan pacul pada lahan yang sama.

b. Persiapan Benih

Jenis benih yang digunakan yaitu lokal dan Vima 1 yang diperoleh dari hasil tanam dari tahun lalu, benih disiapkan berdasarkan luas lahan. Sebelum tanam benih di rendam dengan Cruiser sehingga mempercepat perkecambahan, setelah direndam beberapa jam kemudian benih siap ditanam.

c. Penanaman

Penanaman kacang hijau dilakukan pada bulan Desember dan Januar dengan cara masih sederhana yaitu dengan membuat lubang tanam dengan menggunakan tugal. Kedalaman lubang tanam 2-3 cm disesuaikan dengan ala tunggal yang digunakan, dengan jarak tanam yang diacak karena petani tidak menggunakan jarak tanam yang pasti yakni kurang lebih $40 \mathrm{~cm}$ x $10 \mathrm{~cm}$ atau 20 $\mathrm{cm}$ x $20 \mathrm{~cm}$ dan pada tiap lubang ditanami 2-3 biji kacang hijau.

d. Penyiangan

Penyiangan dilakukan 2 kali yaitu penyiangan pertama dilakukan ketika tanaman berumur 2-4 minggu, sedangkan penyiangan kedua dilakukan apabila tanaman masih tumbuh gulma. Rata-rata penyiangan dilakukan dengan menggunakan alat tajak namun ada petani yang membasmi gulma dengan pestisida seperti Rundup, dan Desis. Tujuan penyiangan adalah membasm gulma yang tumbu disela-sela tanaman atau bersama-sama tanaman menggunakan alat tajak.

e. Pemupukan

Pada usahatani kacang hijau yang dilakukan oleh petani dalam penelitian ini, petani tidak memberikan pupuk kepada tanaman yang dibudidayakan karena petani memandang bahwa tanah garapannya masih subur. Dengan demikian secara ekonomis petani responden ini tidak melakukan pengeluaran untuk pupuk.

f. Panen

Umur tanaman kacang hijau untuk dapat dipanen tergantung dar varietasnya. Untuk varietas Vima 1 sekitar 58-60 hari, sedangkan varietas loka 3 bulan 9 hari. Ciri-ciri tanaman kacang hijau dapat dipanen yaitu polong berwarna cokelat sampai hitam dan kulit polongnya keras atau mengering Polong kacang hijau dipetik satu per satu dengan menggunakan tangan. Untuk varietas yang polongnya matang serempak, pemungutan hasil dapat dilakukan dengan pemotongan tangkai polong.

g. Pasca panen

Cara Untuk memisahkan biji kacang hijau dari kulit polong kacang hijau yaitu kacang hijau dijemur hingga kering, kemudian dimasukkan ke dalam karung selanjutnya dipukul dengan kayu hingga polong pecah. Kemudian biji 
dipisahkan dengan cara ditapis. Biji yang telah bersih dikeringkan dengan cara dijemur, pengeringan dijemur kurang lebih selama 2-3 hari. Kemudian dimasukkan ke dalam tempat yang sudah disediakan.

\subsection{Analisis Pendapatan}

\section{a. Biaya Produksi}

Berdasarkan penggunaan input dapat diperhitungkan biaya produksi yaitu biaya pestisida, biaya transportasi, biaya tenaga kerja, biaya pajak, biaya penyusutan alat yang dapat dirincikan sebagai berikut :

- Biaya pestisida

Berdasarkan hasil penelitian jenis pestisida yang digunakan yaitu roundup, desis, dan cruiser yang digunakan sebelum penanaman. Manfaat roundup dan desis, untuk mengendalikan gulma yang ada dengan harga Rp. 75.000 dan Rp. 15.000, cruiser untuk mempercepat berkecambah dengan harga Rp. 35.000. Biaya pestisida bervariasi tergantung dari jenis pestisida yang digunakan oleh petani responden. Besarnya rata-rata biaya pestisida sebesar Rp. 48.846,-

○ Biaya transportasi

Biaya transportasi biasanya digunakan dalam pembelian input produksi dan penjualan output. Besarnya biaya transportasi tertinggi Rp. 250.000 dan terendah Rp. 100.000, dengan rata-rata biaya transportasi Rp. 160.288,-

- Biaya tenaga kerja

Tenaga kerja merupakan salah satu input yang penting dalam manajemen usahatani kacang hijau. Rata-rata biaya tenaga kerja adalah Rp. 972.418 /HKO,- Biaya penyusutan alat

Berdasarkan hasil penelitian menunjukkan bahwa alat yang digunakan dalam proses kegiatan usahatani kacang hijau di lokasi penelitian terdiri dari: parang, terpal, pacul, dan tajak, rata-rata total penyusutan alat sebesar Rp. 52.103,-

- Biaya pajak

Biaya pajak yang dikeluarkan oleh petani bervariasi tergantung luas lahan dan letak lahan. Besarnya biaya pajak tertinggi Rp. 14.250 dan terendah Rp. 2.500, dengan rata-rata biaya pajak Rp. 6.697. untuk lebih jelas dapat di lihat pada Gambar 1.

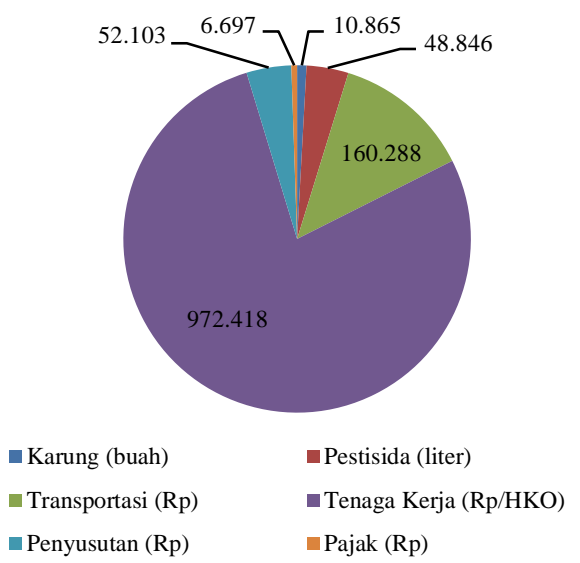

Gambar 1. Rata-rata Biaya Produksi Usahatani Kacang Hijau Satu Kali Produksi Pada Tahun 2016

\section{b. Penerimaan dan Pendapatan}

Pendapatan usahatani kacang hijau merupakan selisih antara penerimaan dari biaya-biaya yang dikeluarkan untuk melakukan usahatani kacang hijau. Sedangkan penerimaan diperoleh dari produksi kacang hijau dikalikan dengan harga jual. Harga jual kacang hijau yaitu Rp. 15.000

Besarnya penerimaan usahatani dapat di lihat pada Gambar 2. dijelaskan rata-rata jumlah penerimaan $\mathrm{Rp}$. 2,744,712,-. Sedangkan besarnya rata-rata pendapatan usahatani kacang hijau sebesar Rp. 1,493,494. Tinggi rendahnya pendapatan tergantung dari biaya yang dikeluarkan, harga jual, dan produksi kacang hijau pada musim tanam 2015/2016.

\section{c. Analisis R/C ratio}

Keuntungan relatif usahatani kacang hijau di lokasi penelitian ditentukan dengan menghitung $\mathrm{R} / \mathrm{C}$ ratio yaitu perbandingan antara total penerimaan usahatani kacang hijau dan total biaya pengeluaran.

Suatu usahatani dapat dikatakan menguntung apabila analisis nilai dari analisis $\mathrm{R} / \mathrm{C}$ ratio lebih besar dari 1 sehingga usahatani tersebut masih bisa dilanjutkan atau layak dan sebaliknya jika nilai dari analisis $\mathrm{R} / \mathrm{C}$ ratio kurang dari 1 maka usahatani tersebut tidak diteruskan. Jika nilai $\mathrm{R} / \mathrm{C}$ ratio sama dengan 1 , ini berarti usaha tersebut tidak menguntungkan dan tidak merugikan atau impas.

Dari hasil penelitian rata-rata $\mathrm{R} / \mathrm{C}$ ratio dari usahatani kacang hijau sebesar 2,2 maka usahatani tersebut secara ekonomis usahatani menguntungkan atau layak, sehingga usahatani tersebut mempunyai prospek yang lebih baik untuk terus dikembangkan.

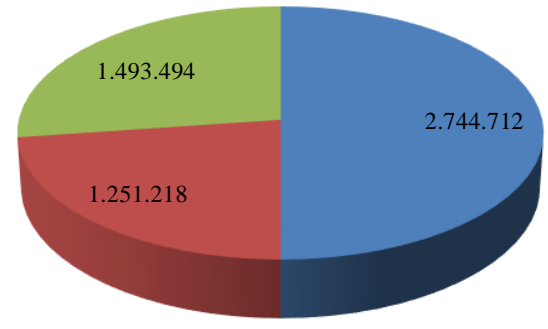

- Penerimaan $(\mathrm{Rp} / \mathrm{Kg}) \quad \square$ Total Biaya Produksi (Rp) $\quad$ Pendapatan (Rp)

Gambar 2. Rata-rata Pendapatan Usahatani Kacang Hijau Satu Kali Produksi Pada Tahun 2016

Hasil penelitian Prasetiaswati \& Radjit, (2015) menunjukkan usahatan kacang hijau di lahan sawah tadah hujan Desa Megonten dan Desa Tempuran Kabupaten Demak menperoleh keuntungan Rp 8.549.000 dan Rp 7.669.666 dengan $\mathrm{B} / \mathrm{C}$ ratio 2,9 dan 2,4 .

\section{Simpulan}

Berdasarkan hasil penelitian dapat digambarkan bahwa usahatani kacang hijau meliputi : Persiapan lahan, dilakukan di lokasi penelitian oleh sebagian petani menggunakan sistem pengolahan lahan (balik tanah) dengan menggunakan pacul dan traktor pada lahan yang sama. Persiapan benih, jenis benih yang digunakan yaitu lokal dan Vima 1 yang diperoleh dari benih yang sudah ada dari tahun lalu. Benih disiapkan berdasarkan luas lahan. Kemudian benih yang disiap disimpan untuk menunggu musim tanam. Penanaman, biasanya dilakukan pada bulan Desember dan Januari dengan cara masih sederhana yaitu dengan membuat lubang tanam dengan menggunakan tugal. Panen biasanya dilakukan dengan mengambil polong yang sudah dibiarkan sampai menghitam atau menguning dari tanaman kacang hijau dengan cara dipetik kemudian untuk memisahkan biji kacang hijau dari kulit polong kacang hijau dengan cara kacang hijau dijemur hingga kering, kemudian dikumpulkan jadi satu tempat beralaskan tikar besar atau terpal lalu diinjak atau dipukul-pukul menggunakan kayu agar biji terpisah dari polongnya. Kacang hijau dijemur kurang lebih 2-3 hari lalu dimasukkan ke dalam tempat yang sudah disediakan. Besarnya pendapatan usahatani kacang hijau tertinggi sebesar Rp. 2.225.125 dan terendah Rp. (2.482) dengan rata-rata Rp. 1.493.494. Tinggi rendahnya pendapatan tergantung dari biaya yang dikeluarkan, harga jual dan produksi kacang hijau pada musim tanam 2015/2016. Sedangkan nilai rata-rata R/C ratio dari usahatani kacang hijau sebesar 2,2 maka usahatani tersebut secara ekonomis menguntungkan sehingga usahatani tersebut mempunyai prospek yang lebih baik untuk terus dikembangkan.

\section{Pustaka}

Badan Pusat Statistik, 2015. Statistik Pertanian Belu, Atambua.

Prasetiaswati, N. \& Radjit, B.S. 2015. Kelayakan Ekonomi dan Respon Petani terhadap Pengembangan Teknologi Produksi Kacang Hijau di Lahan Sawah Tadah Hujan. Iptek Tanaman Pangan, 5(2): 183-196.

Ratna, N.K. 2009. Stilistika: Kajian Puitika Bahasa, Sastra, dan Budaya. Yogyakarta: Pustaka Pelajar.

Rukmana, R. 1997. Kacang Hijau, Budi Daya \& Pascapanen. Jakarta: Kanisius. Soekartawi, 2006. Prinsip Dasar Ekonomi Pertanian (Teori dan Aplikasi). Jakarta: Rajawali Press.

Soekartawi 1995. Analisis Usaha Tani. Universitas Indonesia Press. 